\title{
DAMPAK INTELLECTUAL CAPITAL TERHADAP NILAI PASAR PERUSAHAAN DENGAN RETURN ON ASSET SEBAGAI VARIABEL INTERVENING
}

\author{
Dennis Sutandar ${ }^{1)}$ Prima Apriwenni²) \\ Institut Bisnis dan Informatika Kwik Kian Gie \\ dennis.sutandar@gmail.com ${ }^{1)}$ prima.apriwenni@kwikkiangie.ac.id ${ }^{2}$
}

\begin{abstract}
Nowadays, intellectual capital become a very valuable asset on business. Intellectual Capital is an intangible asset that can create value added and competitive advatage for the company. The value added and competitive advatage will increase investors trust that can cause the raising value of the firm. Intellectual capital was measured by Vallue Added Intellectual Capital that consist of human capital, structural capital, and customer capital. The increasing profit was measured by return on asset (ROA). ROA indicates the company abilities to generate earnings (profitability). The firm value was measured by Tobin's $Q$. The population in this research using a manufacturing company, especially infrastructure, utility, and transportation listed in Indonesia Stock Exchange during the period 2013-2015. Based on purposive sampling method, 19 samples were obtained, so there are 57 of observation data. The analysis techniques use are multiple linear regresion and path analysis. The result of this research showed that: (1) Intellectual capital has a positive and significant influence toward return on assets. (2) Intellectual capital has a positive and significant influence toward firm value. (3) Return on assets has a positive and significant influance on firm value. (4) Intellectual capital has a positive and significant influence toward firm value through return on assets.
\end{abstract}

Keyword : Intellectual Capital, Return on Asset, Firm Value, Tobin's $Q$

\begin{abstract}
ABSTRAK: Intellectual capital pada masa dewasa ini menjadi aset yang sangat bernilai dalam bisnis. Intellectual capital yang merupakan aset tidak berwujud dapat menciptakan nilai tambah dan keunggulan kompetitif bagi perusahaan. Nilai tambah dan keunggulan kompetitif akan meningkatkan kepercayaan investor sehingga memiliki dampak meningkatnya nilai perusahaan. Intellectual capital diukur dengan menggunakan model Value Added Intellectual Capital yang terdiri dari human capital, structural capital, dan customer capital. Peningkatan laba diukur dengan return on asset (ROA), menunjukan kemampuan perusahaan dalam menghasilkan laba (profitabilitas). Nilai perusahaan diukur dengan Tobin's Q. Populasi dalam penelitian ini menggunakan perusahaan manufaktur khususnya infrastruktur, utilitas, dan transportasi yang terdaftar di Bursa Efek Indonesia selama Periode 2013-2015. Berdasarkan metode purposive sampling sampel yang diperoleh sebanyak 19 perusahaan sehingga memperoleh 57 data observasi. Teknik analisis yang digunakan adalah regresi liniear berganda dan analisis jalur. Hasil penelitian ini menunjukan bahwa: (1) Intellectual capital berpengaruh positif dan signifikan terhadap return on asset. (2) Intellectual capital berpengaruh positif dan signifikan terhadap nilai pasar. (3) Return on asset berpengaruh positif dan signifikan terhadap nilai perusahaan. (4) Intellectual capital berpengaruh positif dan signifikan terhadap nilai pasar melalui return on asset.
\end{abstract}

Kata kunci: Modal Intelektual, Return on Asset, Nilai Pasar, Tobins'Q

\section{PENDAHULUAN}

\subsection{Latar Belakang}

Intelectual capital atau modal intelektual pada masa dewasa ini menjadi aset yang sangat bernilai dalam bisnis. Intellectual capital merupakan kombinasi intangible asset dari nilai pasar, intellectual property, sumber daya manusia dan infrastruktur yang memungkinkan perusahaan menjalankan fungsinya dengan baik (Brooking, 1996). Intellectual capital mencakup semua pengetahuan karyawan, organisasi, dan kemampuan perusahaan untuk menciptakan nilai tambah dan keunggulan kompetitif. Intellectual capital adalah aset tak berwujud yang memegang peran penting dalam meningkatkan daya saing perusahaan dan juga dimanfaatkan secara efektif untuk meningkatkan keuntungan perusahaan. Intellectual capital merupakan landasan bagi 
perusahaan untuk berkembang dan mempunyai keunggulan dibandingkan perusahaan lain.

Intellectual capital menarik untuk diteliti karena dapat menciptakan nilai tambah bagi perusahaan. Kapasitas intellectual perusahaan akan meningkatkan kepercayaan investor sehingga memiliki dampak meningkatnya nilai perusahaan. Selain itu, intellectual capital juga dapat meningkatkan peforma kinerja finansial atau profitabilitas perusahaan (Nurmayan, 2015).

Intellectual capital semakin banyak disadari oleh perusahaan dalam dunia bisnis modern. Namun, hal ini bertolak belakang dengan belum dapat diterapkanya pengukuran inttlectual capital secara tepat. Laporan keuangan tradisional belum dapat menyajikan informasi inttelectual capital. Tantangan yang dihadapi sekarang adalah bagaimana para akuntan untuk mengukur, mengidentifikasi, dan mengungkapkanya dalam laporan keuangan. Fenomena ini menuntut para peneliti mencari informasi yang lebih rinci mengenai hal-hal yang berkaitan dengan pengelolaan intellectual capital.

Pulic (1998) memperkenalkan pengukuran intellectual capital dengan menggunakan Vallue Added Intellectual Coefficient $\left(\mathrm{VAIC}^{\mathrm{TM}}\right)$. Metode ini didesain untuk menyajikan informasi tentang value creation efficiency (entitas penciptaan nilai) dari aset berwujud dan aset tidak berwujud yang dimiliki perusahaan. VAIC $^{\mathrm{TM}}$ merupakan metode untuk mengukur kinerja intellectual capital perusahaan. Pendekatan ini relatif mudah dan memungkinkan untuk dilakukan karena menggunakan akun-akun dalam laporan keuangan perusahaan. Komponen utama dari $\mathrm{VAIC}^{\mathrm{TM}}$ dapat dilihat dari sumber daya perusahaan, yaitu physical capital (CEE - capital employed efficiency), human capital (HCE - human capital efficiency), dan structural capital (SCE - structural capital efficiency).

Penelitian ini menggunakan Return on Assets (ROA) sebagai variabel intervening karena merupakan efisiensi biaya yang diperlukan dalam suatu perusahaan. Seberapa besar suatu perusahaan mengelola biayanya seefisien mungkin agar dapat menghasilkan kinerja yang semaksimal mungkin. Efisiensi penciptaan nilai dari aset berwujud dan aset tidak berwujud yang dimiliki perusahaan berdasarkan metode VAIC $^{\text {TM }}$ yang dikembangkan oleh Pulic (1998), yaitu kemampuan perusahaan menciptakan nilai tambah atau Value Added (VA) adalah indikator untuk menilai keberhasilan bisnis. Sehingga efisiensi merupakan kemampuan untuk menciptakan nilai tambah dari pengelolaan komponen intellectual capital yang baik melalui metode $\mathrm{VAIC}^{\mathrm{TM}}$.

Penelitian Dewi dan Isynuwardhana (2014) menggunakan model Pulic untuk menguji hubungan antara intellectual capital dengan nilai pasar dengan menggunakan ROA sebagai variabel intervening. Hasil penelitian ini menunjukkan bahwa intellectual capital tidak memiliki hubungan positif signifikan terhadap nilai pasar secara langsung maupun dengan ROA sebagai variabel intervening. Hasil ini berbeda dengan penelitian yang dilakukan Hadiwijaya dan Rohman (2013) pada perusahaan perbankan yang terdaftar di Bursa Efek Indonesia (BEI) periode 20072011. Dengan menggunakan ROA sebagai variabel intervening, hasil penelitian ini menunjukkan bahwa intellectual capital memiliki hubungan positif dan signifikan terhadap nilai pasar. Hasil positif yang sama juga sesuai dengan penelitian yang dilakukan Suhendra (2015) yang meneliti intellectual capital dan nilai pasar dengan menggunakan ROA sebagai variabel intervening.

Oleh karena hasil yang masih kontradiktif tersebut, maka penelitian ini mencoba untuk meneliti pengaruh intellectual capital terhadap nilai perusahaan dengan return on asset sebagai variabel intervening pada industri manufaktur di Indonesia yang terdaftar di Bursa Efek Indonesia (BEI). Jenis perusahaan manufaktur dipilih karena data perusahaan lengkap dan jenis industrinya beragam. Selain itu, dalam perusahaan manufaktur penilaian kinerja modal intelektual sangat diperlukan. Kinerja modal intelektual dalam perusahaan manufaktur sangat penting karena perusahaan manufaktur dituntut untuk 
selalu membangun strategi dan inovasi baru bagi inovasi produk dan proses. Sehingga pemanfaatan sumber daya manusia dan sumber daya organisasi sangat penting dalam perusahaan manufaktur.

\subsection{Identifikasi Masalah}

Perumusan masalah dalam penelitian ini dapat dirumuskan sebagai berikut: "Apakah Intellectual Capital Berpengaruh Terhadap Nilai Perusahaan melalui ROA Perusahaan?"

\subsection{Tujuan dan Manfaat Penelitian}

Berdasarkan rumusan masalah di atas, maka tujuan penelitian ini adalah:

1. Mengetahui apakah intellectual capital berpengaruh terhadap ROA perusahaan.

2. Mengetahui apakah intellectual capital berpengaruh terhadap nilai perusahaan.

3. Mengetahui apakah ROA perusahaan berpengaruh terhadap nilai perusahaan.

4. Mengetahui apakah intellectual capital berpengaruh terhadap nilai perusahaan melalui ROA perusahaan.

\section{KAJIAN PUSTAKA}

\subsection{Signaling Theory}

Signaling Theory merupakan grand startegy yang mendukung intellectual capital. Teori ini berdasarkan dua asumsi umum. Pertama manajer memiliki informasi yang lebih baik dibandingkan dengan shareholder maupun publik mengenai posisi keuangan perusahaan. Kedua, terkait dengan manajer memiliki keunggulan informasi maka manajer dapat memilih untuk memberikan sinyal kepada publik mengenai posisi keuangan perusahaan (Neysi et al., 2012:309). Terkait dengan intellectual capital, Signaling Theory menyarankan bahwa perusahaan dengan peforma yang baik akan lebih banyak memberikan informasi kepada shareholder dan publik dibandingkan dengan bidang usaha sejenis.

Terdapat lima alasan mengapa perusahaan mengukur intellectual capital (Kamath 2014:53):

1. Untuk membantu perusahaan merumuskan strategi.
2. Mengukur pelaksanaan strategi.

3. Membantu dalam diversifikasi dan memperluas keputusan.

4. Sebagai dasar dalam memberikan kompensasi, dan

5. Sebagai langkah komunikasi kepada eksternal stakeholders.

Dengan alasan diatas maka manajer dapat mempertimbangkan apakah informasi yang berkaitan dengan intellectual capital harus dipublikasikan atau hanya diigunakan untuk kepentingan internal. Apabila informasi tersebut dapat meberikan dampak atau sinyal positif kepada shareholder dan publik dibandingkan dengan risiko pengukngkapan informasi tersebut, maka manajer dapat mengungkapkanya.

\subsection{Resource Based Theory}

Resources Based Theory sering juga dikenal dengan Resource Based View (RBV) memandang perusahaan sebagai sekumpulan aset fisik dan aset tidak berwujud serta kemampuan perusahaan memperoleh, mengelola, dan mempertahankan sumber daya (Khotimah, 2014:2). Perbedaan sumber daya dan kemampuan perusahaan dengan perusahaan pesaing akan memberikan keuntungan kompetitif (Peteraf, 1993). Asusmsi RBV yaitu bagaimana perusahaan dapat bersaing dengan perusahaan lain untuk mendapatkan keunggulan kompetitif dengan mengelola sumber daya yang dimilikinya sesuai dengan kemampuan perusahaan.

Sumber daya perusahaan dapat dibagi menjadi tiga macam yaitu berwujud, tidak berwujud dan sumber daya manusia. Kemampuan menunjukkan apa yang dapat dilakukan perusahaan dengan sumber dayanya. Pendekatan RBV menyatakan bahwa perusahaan dapat mencapai keunggulan bersaing yang berkesinambungan dan memperoleh keuntungan superior dengan memiliki atau mengendalikan aset-aset strategis baik yang berwujud maupun yang tidak berwujud.

Barney (1986) membuat daftar mengenai segala asset, kemampuan, proses, atribut, informasi, dan sebagainya yang 
dikelompokan sebagai sumber daya. Lalu Barney (1991) mengidentifikasikan karakteristik sumber daya tersebut dan mengemukakan 4 kriteria yang menurutnya penting secara strategis yang akan memberikan keunggulan kompetitif, yakni:

1. Valuable - sumber daya bisa menciptakan nilai yang lebih bagi perusahaan.

2. Rare - sumber daya tersebut langka dan terbatas.

3. Inimitable - sumber daya tersebut tidak dapat ditiru oleh pesaing.

Non-substtitutable - sumber daya tersebut tidak dapat digantikan oleh sumber daya yang lain..

\subsection{Intellectual Capital}

Intellectual capital pertama kali dipublikasikan oleh Galbraith pada tahun 1969. Galbraith mengungkapkan bahwa intellectual capital bukan hanya sekedar "kecerdasan murni" tetapi lebih kepada tingkatan "tindakan intelektual". intellectual capital merupakan pengumpulan ide-ide (Bontis, 1998).

Intellectual capital adalah informasi dan pengetahuan yang diaplikasikan dalam pekerjaan untuk menciptakan nilai (Purnomosidhi, 2006). Intellectual capital adalah keseluruhan dimensi dari perusahaan, yaitu relasi dengan pelanggan, tenaga kerja perusahaan dan prosedur pendukung yang diciptakan dengan adanya inovasi, modifikasi pengetahuan saat ini, transfer ilmu pengetahuan dan pembelajaran yang berkelanjutan yang akhirnya dapat meningkatkan nilai perusahaan (Gozali dan Hatane, 2014:206). Intellectual capital telah diidentifikasi sebagai seperangkat tak berwujud (sumber daya, kemampuan dan kompetensi) yang menggerakkan kinerja organisasi dan penciptaan nilai (Bontis, 1998:67). Dari definisi tersebut dapat disimpulkan bahwa modal intelektual merupakan sumber daya yang dimiliki oleh suatu perusahaan yang nantinya akan memberikan keuntungan di masa depan yang dilihat dari kinerja keuangan perusahaan sehingga meningkatkan nilai perushaan tersebut.
Secara umum, elemen-elemen dalam intellectual capital terdiri dari human capital (HC), Structural Capital (SC), dan Customer Capital (CC) (Bontis et al., 2000). Definisi dari masing-masing komponen modal intelektual yaitu:

\section{Human capital (HC)}

Human Capital merupakan modal yang terkait dengan pengembangan sumber daya manusia perusahaan, seperti kompetensi, komitmen, motivasi, dan loyalitas karyawan. Human Capital menunjukkan kemampuan perusahaan dalam mengelola sumber daya manusia. Human capital yang merupakan komponen intellectual capital menganggap manusia sebagai aset yang bernilai karena pengetahuan yang dimiliki (Salim dan Karyawati, 2013:56). Menurut Bontis (1998:65) human capital adalah kombinasi dari pengetahuan, skill, kemampuan melakukan inovasi dan kemampuan menyelesaikan tugas, meliputi nilai perusahaan, kultur dan filsafatnya. Jika perusahaan berhasil dalam mengelola pengetahuan karyawannya, maka hal itu dapat meningkatkan human capital. Sehingga human capital merupakan kekayaan yang dimiliki oleh suatu perusahaan yang terdapat dalam tiap individu yang ada di dalamnya. Human capital ini yang nantinya akan mendukung structural capital dan customer capital.

\section{Structural capital (SC)}

Structural Capital merupakan modal yang dimiliki oleh perusahaan, meliputi pengetahuan yang akan tetap berada dalam perusahaan. Intellectual capital jenis ini terdiri dari rutinitas perusahaan, prosedur, sistem, budaya, dan database (Salim dan Karyawati, 2013:56). Menurut Stewart (1997) modal struktural adalah tempat untuk mengemas modal manusia dan memungkinkannya untuk digunakan berulang-ulang dalam menciptakan nilai tambah.

Bontis (1999) memperjelas bahwa modal struktural adalah pengetahuan yang melekat di dalam rutinitas perusahaan. Bontis juga mengemukakan bahwa perusahaan dengan modal struktural yang kuat akan memiliki budaya yang mendukung agar 
memungkinkan individu untuk mencoba suatu hal, untuk gagal, untuk belajar, dan untuk mencoba lagi. Bontis menggambarkan modal struktural sebagai "apa yang tersisa di perusahaan ketika karyawan pulang untuk tidur". Modal struktural muncul dari proses-proses dan nilai yang diciptakan perusahaan, yang mencerminkan fokus eksternal dan internal perusahaan ditambah nilai pembaharuan dan pengembangan untuk masa depan.

\section{Customer capital (CC) atau Relational capital (RC)}

Customer Capital adalah orang-orang yang berhubungan dengan perusahaan, yang menerima pelayanan yang diberikan oleh perusahaan tersebut. Menurut Sawarjuwono (2003) elemen customer capital merupakan komponen modal intelektual yang memberikan nilai secara nyata. Customer capital membahas mengenai hubungan perusahaan dengan pihak di luar perusahaan seperti pemerintah, pasar, pemasok dan pelanggan, bagaimana loyalitas pelanggan terhadap perusahaan. Customer capital juga dapat diartikan kemampuan perusahaan untuk mengidentifikasi kebutuhan dan keinginan pasar sehingga menghasilkan hubungan baik dengan pihak luar (Suhendah, 2012).

Stewart (1998) memperjelas bahwa hubungan dari ketiga elemen ini tidak dapat berdiri sendiri, namun harus saling berinteraksi satu sama lain untuk dapat menciptakan intellectual capital.

\subsection{Value Added Intellectual Capital $\left(V_{A I C}{ }^{T M}\right)$}

Pulic (1998) menemukan pengukuran secara tidak langsung modal intelektual yaitu Metode value added intellectual coefficient (VAIC ${ }^{\mathrm{TM}}$ ), pengukuran ini bertujuan menyajikan informasi tentang efisiensi penciptaan nilai dari aset berwujud (tangible asset) dan aset tidak berwujud (intangible assets) yang dimiliki perusahaan. VAIC ${ }^{\text {TM }}$ merupakan pengukuran untuk mengukur kinerja intellectual capital perusahaan dengan perhitungan yang mudah karena datanya ada dalam laporan keuangan. Beberapa alasan utama yang mendukung penggunaan VAIC $^{\mathrm{TM}}$ diantaranya yaitu yang pertama, VAIC $^{\mathrm{TM}}$ menyediakan dasar ukuran standard dan konsisten, angka-angka keuangan yang standar yang umumnya tersedia dari laporan keuangan perusahaan, sehingga memungkinkan lebih efektif melakukan analisis komparatif internasional menggunakan ukuran sampel yang besar di berbagai sektor industri. Kedua, semua data yang digunakan dalam perhitungan didasarkan pada infromasi yang telah diaudit, sehingga perhitungan dapat dianggap obyektif dan dapat diverifikasi.

Model ini dimulai dengan menghitung value added. Value added adalah indikator paling objektif untuk menilai keberhasilan bisnis dan menunjukkan kemampuan perusahaan dalam penciptaan nilai (value creation). Value added dapat dihitung dengan menghitung selisih output dan input.

Metode VAIC mengukur efisiensi tiga jenis input perusahaan, yaitu modal manusia, modal struktural serta modal fisik dan financial yang terdiri dari:

1. Human Capital Efficiency (HCE)/VAHU adalah indikator efisiensi nilai tambah modal manusia. HCE merupakan rasio dari Value Added (VA) terhadap Human Capital (HC). Hubungan ini mengindikasikan kemampuan modal manusia membuat nilai pada sebuah perusahaan. HCE dapat diartikan juga sebagai kemampuan perusahaan menghasilkan nilai tambah setiap rupiah yang dikeluarkan pada modal manusia. HCE menunjukkan berapa banyak Value Added (VA) dapat dihasilkan dengan dana yang dikeluarkan untuk tenaga kerja (Ulum, 2007).

\section{Structural Capital Efficiency} (SCE)/STVA adalah indikator efisiensi nilai tambah modal struktural. SCE merupakan rasio dari SC terhadap VA. Rasio ini mengukur jumlah SC yang dibutuhkan untuk menghasilkan 1 rupiah dari VA dan merupakan indikasi 
bilamana keberhasilan SC dalam penciptaan nilai (Tan et al., 2007).

Capital Employed Efficiency (CEE)/VACA adalah indikator efisiensi nilai tambah modal yang digunakan. CEE merupakan rasio dari VA terhadap CE. CEE menggambarkan berapa banyak nilai tambah perusahaan yang dihasilkan dari modal yang digunakan CEE yaitu kalkulasi dari mengelola modal perusahaan.

\subsection{Return on Assets (ROA)}

Menurut Chen et al. (2005), ROA adalah indikator efisiensi perusahaan dalam memanfaatkan asset yang ada dan mengendalikan firm's financing policies. Menurut Home dan Wachowicz (2005), ROA mengukur efektivitas keseluruhan dalam menghasilkan laba melalui aktiva yang tersedia. Daya untuk menghasilkan laba dari modal yang diinvestasikan. Dan menurut Sawir (2005), ROA merupakan rasio yang digunakan untuk mengukur kemampuan manajemen perusahnaan dalam memperoleh (laba) secara keseluruhan. Semakin besar ROA suatu perusahaan, semakin besar pula tingkat keuntungan yang dicapai perusahaan dan semakin baik pula posisi perusahaan tersebut dari segi pengunaan asset. Sawir menghitung ROA dengan membagi laba bersih (net income) perusahaan dengan total aset dikalikan dengan seratus persen.

\subsection{Nilai Perusahaan}

Nurlela dan Islahuddin (2008:7) menjelaskan bahwa enterprise value (EV) atau dikenal juga sebagai firm value (nilai perusahaan) merupakan konsep penting bagi investor, karena merupakan indikator bagi pasar menilai perusahaan secara keseluruhan. Sedangkan dalam Wahyudi dan Pawestri (2006) diungkapkan bahwa nilai perusahaan merupakan persepsi investor terhadap perusahaan, yang sering dikaitkan dengan harga saham. Harga saham yang tinggi membuat nilai perusahaan juga tinggi. Nilai perusahaan yang dibentuk melalui indikator nilai pasar saham sangat dipengaruhi oleh peluangpeluang investasi. Pengeluaran investasi memberikan sinyal positif tentang pertumbuhan perusahaan di masa yang akan datang, sehingga meningkatkan harga saham sebagai indikator nilai perusahaan (signaling theory). Berdasarkan penjelasan diatas, maka nilai perusahaan adalah nilai pasar yang dihasilkan dari harga saham yang beredar pada suatu perusahaan dibandingkan dengan nilai bukunya. Jika nilai pasar ekuitas lebih tinggi dari nilai bukunya, maka nilai perusahaan tersebut meningkat.

Menurut Weston dan Copeland (2008) dikenal beberapa cara untuk mengukur nilai perusahaan seperti, price earning ratio, price to book value, dan rasio Tobin's Q. Rasio price earning ratio (PER) menggambarkan apresiasi pasar terhadap kemampuan perusahaan dalam menghasilkan laba. Rasio ini dihitung dengan membagi harga pasar per saham dengan laba per saham. Dalam penelitian Wahyudi dan Pawestri (2006) nilai perusahaan diukur dengan Price to Book Value (PBV). Rasio ini mengukur nilai yang diberikan pasar keuangan pada manajemen dan organisasi perusahaan sebagai sebuah perusahaan yang terus tumbuh. PBV dihitung dengan membagi harga pasar per lembar saham dengan nilai buku per lembar saham.

Terdapat cara lain yang digunakan untuk mengukur nilai perusahaan adalah dengan menggunakan Tobin's Q. Tobin's Q adalah suatu rasio yang dikembangkan oleh Profesor James Tobin (1967). Rasio ini merupakan konsep yang berharga karena menunjukkan estimasi pasar keuangan saat ini tentang nilai hasil pengembalian dari setiap dolar investasi inkremental. Jika nilai Tobin's Q di atas satu, ini menunjukkan bahwa investasi dalam aktiva menghasilkan laba yang memberikan nilai yang lebih tinggi daripada pengeluaran investasi, hal ini akan merangsang investasi baru. Jika nilai Tobin's Q di bawah satu, investasi dalam aktiva tidaklah menarik. Jadi Tobin's Q merupakan ukuran yang lebih teliti tentang seberapa efektif manajemen memanfaatkan sumber-sumber daya ekonomis dalam kekuasaannya. 
Wernerfelt dan Montgomery (1988) menyimpulkan bahwa Tobin's Q dapat digunakan sebagai alat ukur dalam menentukan kinerja perusahaan. Dalam penelitian ini, nilai perusahaan diukur dengan menggunakan proksi Tobin's Q.

Gambar dibawah ini menunjukan kerangka pemikiran pengaruh intellectual capital terhadap nilai perusahaan dengan return on asset sebagai variabel intervening sebagai berikut:

Gambar 1

Kerangka Pemikiran

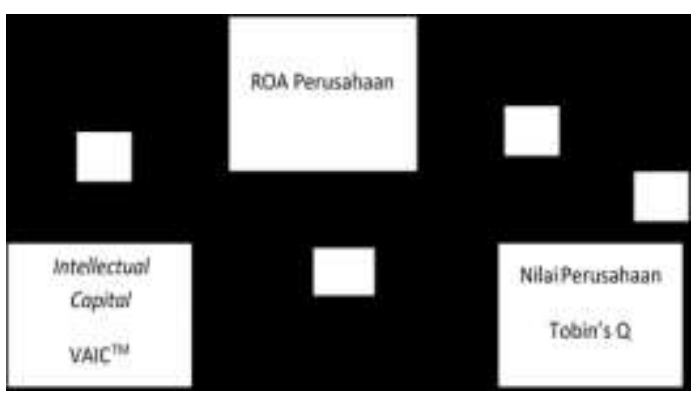

Berdasarkan model penelitian diatas, maka dapat dibuat Hipotesis Alternatif (Ha) sebagai berikut:

Ha1: Terdapat pengaruh positif Intellectual Capital terhadap ROA perusahaan.

Ha2: Terdapat pengaruh positif Intellectual Capital terhadap nilai perusahaan

Ha3: Terdapat pengaruh positif ROA perusahaan dengan nilai perusahaan.

Ha4: Terdapat pengaruh positif Intellectual Capital terhadap nilai perusahaan melalui ROA perusahaan.

\section{METODE PENELITIAN}

\section{1 Obyek Penelitian}

Objek penelitian pada penelitian ini adalah perusahaan manufaktur khususnya industri sektor tujuh yaitu perusahaan yang termasuk dalam perusahaan infrastruktur, utilitas, dan transportasi yang listing dan go public di Bursa Efek Indonesia selama periode tahun 2013-2015, sejumlah 19 perusahaan. Perusahaan tersebut dipilih karena peneliti yakin bahwa perusahaan yang termasuk dalam perusahaan infrastruktur, utilitas, dan transportasi memenuhi kriteria-kriteria sebagai perusahaan

"new economy" yang mendapatkan banyak kontribusi dari modal intelektual. Sementara itu, sampel merupakan bagian dari populasi yang digunakan sebagai objek penelitian. Sampel tersebut sudah bisa mewakili adanya populasi. Tidak semua perusahaan yang dapat digunakan untuk penelitian ini.

\section{2 Teknik Pengumpulan Data}

Dalam penelitian ini, pengumpulan data dilakukan secara pengamatan (observasi), yaitu dengan cara melakukan pengamatan terhadap data sekunder. Data sekunder yang digunakan dalam peneltian ini sebagai berikut:

1. Data tentang nama perusahaan dan jenis perusahaan, bisnis yang dijalankan perusahaan yang diperoleh dari Indonesian Capital Market Directory (ICMD) 2013-2015.

2. Data keuangan perusahaan tahun 20132015 yang diperoleh dari pusat data pasar modal Kwik Kian Gie School of Business (IBII) dan juga dari situs resmi BEI (www.idx.co.id).

\section{3 Teknik Pengambilan Sampel}

Teknik pengambilan sampel yang digunakan dalam penelitian ini adalah purposive sampling dengan kriteria sebagai berikut:

1. Perusahaan harus menerbitkan laporan keuangan berturut-turut dari tahun 20132015 yang telah dipublikasikan.

2. Perusahaan yang memiliki nilai buku ekuitas yang negatif tidak dimasukkan ke dalam sampel.

3. Perusahaan yang menderita rugi tidak dimasukkan dalam sampel.

Variabel Penelitian

Variabel Independen 
Variabel independen dalam penelitian ini adalah intellectual capital (IC) yang diukur berdasarkan value added (VA) yang diciptakan oleh human capital (VAHU), physical capital (VACA) dan structural capital (STVA). Kombinasi dari ketiga value added tersebut disimbolkan dengan nama VAIC ${ }^{\text {TM }}$ yang dikembangkan oleh Pulic (1998: 1999: 2000).

Formulasi perhitungan VAIC'M adalah sebagai berikut (Ulum: 2007):

1. Output $(\mathrm{OUT})=$ Total penjualan dan pendapatan lain.

2. Input (IN) = Beban dan biaya-biaya (selain beban karyawan).

3. Value Added (VA) = Selisih antara Output dan Input.

$$
\mathbf{V A}=\boldsymbol{O U T}-\boldsymbol{I N}
$$

4. Human Capital $(\mathrm{HC})=$ Beban karyawan

5. Capital Emploed / Capital Coefficient $(\mathrm{CA})=$ Dana yang tersedia (ekuitas dan laba bersih)

6. Structural Capital $(\mathrm{SC})=\mathrm{VA}-\mathrm{HC}$

7. Value Added Capital Caefficient (VACA) adalah rasio dari VA terhadap CA. Rasio ini menunjukkan kontribusi yang dibuat oleh setiap unit dari CA terhadap value added organisasi.

$$
\text { VACA }=\text { VA / CA }
$$

8. Value Added Human Capital (VAHU) adalah rasio dari VA terhadap HC. Rasio ini menunjukkan kontribusi yang dibuat oleh setiap rupiah yang diinvestasikan dalam HC terhadap value added organisasi. Menurut Ze'ghal dan Maaloul (2010) beban karyawan tidak dimasukkan dalam biaya melainkan investasi.

$$
\text { VAHU }=\text { VA } / \text { HC }
$$

9. Structural Capital Value Added (STVA) adalah rasio dari SC terhadap VA. Rasio ini mengukur jumlah $\mathrm{SC}$ yang dibutuhkan untuk menghasilkan 1 rupiah dari VA dan merupakan indikasi bagaimana keberhasilan SC dalam penciptaan nilai. SC tergantung pada penciptaan VA dan berbanding terbalik dengan $\mathrm{HC}$.

$$
\text { STVA }=\text { SC } / \text { VA }
$$

10.Value Added Intellectual Coefficient (VAIC ${ }^{\mathrm{TM}}$ ) mengindikasi kemampuan intelektual organisasi. VAIC ${ }^{\text {TM }}$ dapat juga dianggap sebagai BPI (Businesss

Performance Indikator).

VAIC $^{\text {TM }}=$ VACA + VAHU + STVA

Variabel Dependen

Variabel dependen dalam penelitian ini adalah nilai perusahaan. Nilai perusahaan pada penelitian ini diproksikan dengan Tobin's $Q$.

TOBIN'S $Q=(\mathrm{MVE}+\mathrm{DEBT}) / \mathrm{TA}$

Keterangan:

Tobin's $Q \quad=$ Nilai perusahaan

MVE $=$ Closing price $\mathrm{x} \mathrm{q}$ shares

DEBT $\quad=$ Total utang perusahaan

TA $\quad=$ Total aktiva

Variabel Intervening

Variabel intervening merupakan variabel antara atau mediating yang berfungsi memediasi hubungan antara variabel independen dengan variabel dependen. Variabel intervening dalam penelitian ini adalah ROA perusahaan. Rasio ROA (Return on Asets) digunakan sebagai proksi kinerja keuangan perusahaan. ROA merupakan indikator keuangan yang menggambarkan kemampuan perusahaan dalam menghasilkan laba atas total aset yang dimiliki perusahaan. ROA menggambarkan keuntungan bisnis dan efisiensi yang dilakukan perusahaan dalam pemanfaatan total aset (Chen et al, 2005). Cara perhitungan ROA adalah sebagai berikut (Horne, 2005):

ROA = Laba Bersih / Total Aktiva

Analisis Regresi Linear Berganda

Analisis regresi pada dasarnya menyangkut studi tentang hubungan antara satu variabel yang disebut variabel tak bebas atau variabel yang dijelaskan dan satu atau lebih variabel lain yang disebut variabel bebas atau variabel penjelas (Gujarati, 2006a:115). Analisis regresi digunakan untuk mengukur kekuatan hubungan antara dua variabel atau lebih. Selain itu analisis regresi dilakukan untuk menunjukkan arah hubungan positif maupun negatif antara variabel dependen dengan variable independen (Ghozali, 2009). Penelitian ini 
akan menguji empat hipotesis yang telah disusun. Untuk menguji keempat hipotesis tersebut maka model penelitian ini menjadi sebagai berikut:

a. Model 1

$$
\mathrm{ROA}=\mathrm{b}_{0}+\mathrm{b}_{1} \mathrm{IC}+\varepsilon
$$

b. Model 2

$$
\mathrm{NP}=\mathrm{b}_{0}+\mathrm{b}_{1} \mathrm{ROA}+\mathrm{b}_{2} \mathrm{IC}+\varepsilon
$$

Keterangan:

$$
\begin{aligned}
& \mathrm{ROA}=\text { Return on Assets } \\
& \mathrm{VAIC}=\text { Value Added Intellectual Capital } \\
& \mathrm{NP} \quad=\text { Nilai Perusahaan }
\end{aligned}
$$

Analisis Jalur

Analisis jalur merupakan perluasan dari analisis regresi linear berganda, atau analisis jalur adalah penggunaan analisis regresi untuk menaksir hubungan kausalitas antar variabel yang telah ditetapkan sebelumnya berdasarkan teori (Ghozali, 2006:210). Ghozali juga mengungkapkan bahwa terdapat dua hubungan dalam analisis jalur, hubungan langsung dan tidak langsung. Hubungan langsung terjadi jika satu variabel memengaruhi variabel lainnya tanpa ada variabel ketiga yang memediasi hubungan kedua variabel tadi. Sedangkan hubungan tidak langsung terjadi jika ada variabel ketiga yang memediasi hubungan kedua variabel ini.

Persamaan yang terbentuk adalah sebagai berikut:

$$
\begin{array}{ll}
\mathrm{ROA} & =\rho \mathrm{ROA} \cdot \mathrm{VAIC}+\varepsilon \\
\mathrm{NP} & =\rho \mathrm{NP} \cdot \mathrm{VAIC}+\rho \mathrm{NP} \cdot \mathrm{ROA}+\varepsilon
\end{array}
$$

Untuk pengaruh langsung yang ditimbulkan oleh variabel independen kepada dependen dapat dilihat dengan standardized coefficients yang dihasilkan oleh SPSS 23 . Untuk melihat pengaruh tidak langsung harus dihitung dengan mengalikan koefisien tidak langsungnya yang dapat dilihat dari standardized coefficients. Untuk menghitung error $(\varepsilon)$ menggunakan rumus:

$\varepsilon=\sqrt{1-\mathrm{R}^{2}}$

Error merefleksikan keragaman yg tidak dapat dijelaskan (pengaruh dari variabel yg tidak terukur) dan kesalahan pengukuran..

\section{HASIL DAN PEMBAHASAN}

4.1. Analisis Deskriptif

Tabel 1

Statistik Deskriptif

\begin{tabular}{lccccc}
\hline \multicolumn{1}{c}{ Periode } & $\mathrm{N}$ & Min & Maks & Rata-rata & Deviasi Std \\
\hline $\begin{array}{l}\text { Sebelum adopsi penuh IFRS } \\
\text { (2010-2011) }\end{array}$ & & & & & \\
PRICE & 32 & 610 & 33.000 & $10.206,4634$ & $8.112,96107$ \\
EPS & 32 & 30 & 1.657 & 544,6709 & 477,35062 \\
BVPS & 32 & 356,49 & $7.373,71$ & $2.216,2588$ & $1.722,88468$ \\
\hline Sesudah adopsi penuh IFRS & & & & & \\
(2012-2015) & & & & & \\
PRICE & 64 & 1.045 & 42.925 & $11.401,3381$ & $9.087,10995$ \\
EPS & 64 & 24 & $1.590,4$ & 630,6683 & 458,70219 \\
BVPS & 64 & 157,26 & $10.522,88$ & $3.354,538$ & $2.631,69029$ \\
\hline
\end{tabular}

Sumber: data sekunder yang diolah, 2017

Berdasarkan tabel 1, menunjukkan bahwa terdapat peningkatan rata-rata harga saham sebelum periode adopsi penuh IFRS yaitu sebesar 10.206,4634 menjadi 11.401,3381. Namun harga saham menjadi lebih berfluktuatif setelah adopsi penuh IFRS dengan standar deviasi dari 8.112,96107 menjadi $9.087,10995$. Rata-rata laba bersih per lembar saham (EPS) mengalami peningkatan pada periode sesudah adopsi penuh IFRS yaitu dari 544,6709 menjadi 630,6683 . Hal tersebut juga diikuti dengan peningkatan rata-rata nilai buku ekuitas per lembar saham (BVPS) dari 2.216,2588 menjadi 3.354,538. 


\subsection{Uji Kesamaan Koefisien}

Tabel 2

Hasil Uji Kesamaan Koefisien

\begin{tabular}{|c|c|c|}
\hline \multicolumn{2}{|c|}{ Variabel } & Sig. \\
\hline & (Constant) & .226 \\
\hline & EPS & .000 \\
\hline & BVPS & .077 \\
\hline & DT1 & .879 \\
\hline & EPS_DT1 & .252 \\
\hline & BVPS_DT1 & .282 \\
\hline & Variabel & Sig. \\
\hline 1 & (Constant) & .100 \\
\hline & EPS & .013 \\
\hline & BVPS & .285 \\
\hline & DT1 & .413 \\
\hline & DT2 & .661 \\
\hline & DT3 & .897 \\
\hline & EPS_DT1 & .633 \\
\hline & EPS_DT2 & .191 \\
\hline & EPS_DT3 & .892 \\
\hline & BVPS_DT1 & .799 \\
\hline & BVPS_DT2 & .430 \\
\hline & BVPS_DT3 & .701 \\
\hline
\end{tabular}

Hasil uji koefisien untuk model regresi menunjukkan bahwa pada periode sebelum adopsi penuh IFRS nilai signifikansi $p$ value variabel $\mathrm{DT}_{1}, \quad \mathrm{EPS}^{*} \mathrm{DT}_{1}$, dan BVPS*DT $_{1}$ serta pada periode sesudah adopsi penuh IFRS nilai signifikansi $p$ value variabel $\mathrm{DT}_{1}, \mathrm{DT}_{2}, \mathrm{DT}_{3}, \mathrm{EPS}^{*} \mathrm{DT}_{1}$, $\mathrm{EPS}^{*} \mathrm{DT}_{2}, \quad \mathrm{EPS}^{*} \mathrm{DT}_{3}, \quad \mathrm{BVPS}^{*} \mathrm{DT}_{1}$, BVPS*DT 2 , dan BVPS*DT 3 lebih besar dari $\alpha(0,05)$. Hasil ini berarti tidak ada perbedaan koefisien pada model regresi sehingga data dapat di-pooling. Hasil uji kesamaan regresi dapat dilihat di tabel 2 .

\subsection{Uji Asumsi Klasik}

\section{a. Uji Normalitas}

Hasil pengujian pada tabel 3 menunjukkan bahwa nilai probabilitas atau Asymp. Sig. (2-tailed) pada periode sebelum dan sesudah adopsi penuh IFRS sebesar 0,200. Dengan demikian nilai probabilitas lebih besar dari 0,05 . Oleh karena itu, maka tidak tolak Ho yang berarti data residual berdistribusi normal.
Tabel 3

Hasil Uji Normalitas

\begin{tabular}{ccc}
\hline Periode & $\begin{array}{c}\text { Kolmogorov- } \\
\text { Smirnov Z } \\
\text { Unstandardized } \\
\text { residual }\end{array}$ & $\begin{array}{c}\text { Asymp. } \\
\text { Sig. } \\
(2- \\
\text { tailed })\end{array}$ \\
\hline $\begin{array}{c}\text { Sebelum } \\
\text { adopsi } \\
\text { penuh IFRS } \\
\text { (2010- } \\
\text { 2011) }\end{array}$ & 0,122 & 0,200 \\
\hline $\begin{array}{c}\text { Sesudah } \\
\text { adopsi }\end{array}$ & & \\
penuh IFRS \\
(2012- \\
2015)
\end{tabular}

Sumber: data sekunder yang diolah, 2017

\section{b. Uji Multikolonieritas}

Hasil pengujian pada tabel 4 menunjukkan tidak ada variabel independen yang memiliki nilai tolerance kurang dari 0,1. Dimana pada periode sebelum dan sesudah adopsi penuh IFRS memiliki nilai tolerance masing-masing sebesar 0,290 dan 0,328 . Hal tersebut berarti bahwa tidak ada korelasi antar variabel independen yang nilainya lebih dari 95\%. Hasil perhitungan nilai Variance Inflation Factor (VIF) juga menunjukkan hal yang sama bahwa tidak ada satupun variabel independen yang memiliki nilai VIF lebih dari 10. Dimana pada periode sebelum dan sesudah adopsi penuh IFRS memiliki nilai VIF masingmasing sebesar 3,450 dan 3,049. Jadi dapat disimpulkan bahwa tidak terjadi multikolonieritas atar variabel independen dalam model regresi.

Tabel 4

Hasil Uji Multikolonieritas

\begin{tabular}{cccc}
\hline Periode & Variabel & Tolerance & VIF \\
\hline $\begin{array}{c}\text { Sebelum } \\
\text { adopsi }\end{array}$ & & & \\
penuh & EPS & 0,290 & 3,450 \\
IFRS & BVPS & 0,290 & 3,450 \\
$(2010-$ & & & \\
2011) & & & \\
\hline Sesudah & & & \\
adopsi & & & \\
penuh & EPS & 0,328 & 3,049 \\
IFRS & BVPS & 0,328 & 3,049 \\
$(2012-$ & & & \\
2015) & & & \\
\hline
\end{tabular}


Sumber: data sekunder yang diolah, 2017

\section{c. Uji Autokorelasi}

Hasil pengujian pada tabel 5 menunjukkan bahwa pada periode sebelum dan sesudah adopsi penuh IFRS memiliki nilai test masing-masing sebesar $-0,00321$ dan $-0,01468$. Nilai probabilitas pada periode sebelum dan sesudah adopsi penuh IFRS sebesar 0,208 dan 0,078 dimana kedua nilai probabilitas tersebut diatas 0,05 yang berarti tidak tolak Ho, sehingga dapat disimpulkan bahwa residual random atau tidak terjadi autokorelasi antar nilai residual baik pada periode sebelum dan sesudah adopsi penuh IFRS.

Tabel 5

\begin{tabular}{ccc}
\multicolumn{3}{c}{ Hasil Uji Autokorelasi } \\
\hline Periode & $\begin{array}{c}\text { Test } \\
\text { Value }\end{array}$ & $\begin{array}{c}\text { Asymp. } \\
\text { Sig. }(2- \\
\text { tailed })\end{array}$ \\
\hline Sebelum & & \\
adopsi & & \\
penuh & - & 0,208 \\
IFRS & 0,00321 & \\
$(2010-$ & & \\
2011) & & \\
\hline Sesudah & & \\
adopsi & - & 0,078 \\
penuh & - & \\
IFRS & 0,01468 & \\
$(2012-$ & & \\
2015) & & \\
\hline
\end{tabular}

Sumber: data sekunder yang diolah, 2017

\section{d. Uji Heteroskedastisitas}

Hasil pengujian pada tabel 6 menunjukkan bahwa semua nilai sig. pada periode sebelum dan sesudah adopsi penuh IFRS lebih besar dari 0,05 , sehingga tidak ada satupun variabel independen yang signifikan secara statistik mempengaruhi variabel dependen $\left(\operatorname{LnU}^{2} \mathrm{i}\right)$. Jadi dapat disimpulkan bahwa model regresi tidak terdapat heteroskedastisitas baik pada periode sebelum maupun sesudah adopsi penuh IFRS.

\section{Tabel 6}

Hasil Uji Heteroskedastisitas

\begin{tabular}{ccccc}
\hline Periode & Dependen & Independen & $\mathrm{t}$ & Sig. \\
\hline Sebelum & LnU $^{2} \mathrm{i}$ & LnEPS & 0,638 & 0,529 \\
adopsi & & LnBVPS & - & 0,356 \\
penuh & & & 0,939 & \\
IFRS & & & & \\
$(2010-$ & & & & \\
$2011)$ & & & & \\
\hline Sesudah & LnU $^{2} \mathrm{i}$ & LnEPS & 0,375 & 0,709 \\
adopsi & & LnBVPS & - & 0,590 \\
penuh & & & 0,541 & \\
IFRS & & & & \\
$(2012-$ & & & & \\
2015) & & & & \\
\hline Sumber: & & & & \\
\hline
\end{tabular}

Sumber: data sekunder yang diolah, 2017

\subsection{Analisis Regresi Berganda}

a. Uji F

Hasil pengujian pada tabel 7 menujukkan nilai $\mathrm{F}$ hitung pada periode sebelum dan sesudah adopsi penuh IFRS masing-masing sebesar 93,888 dan 146,874 dengan probabilitas 0,000 . Karena probabilitasnya jauh lebih kecil dari 0,05 , maka model regresi baik pada periode sebelum maupun sesudah adopsi penuh IFRS dapat digunakan untuk memprediksi harga saham atau dapat dikatakan bahwa EPS dan BVPS secara bersama-sama berpengaruh terhadap harga saham.

Tabel 7

Hasil Uji F

\begin{tabular}{ccccccc}
\hline Periode & & Sum of & df & $\begin{array}{c}\text { Mean } \\
\text { Square }\end{array}$ & F & Sig. \\
\hline Sebelum & Regression & 23,840 & 2 & 11,920 & 93,888 & 0,000 \\
adopsi & Residual & 3,682 & 29 & 0,127 & & \\
penuh & Total & 27,522 & 31 & & & \\
IFRS & & & & & & \\
$(2010-$ & & & & & & \\
$2011)$ & & & & & & \\
\hline
\end{tabular}




\begin{tabular}{ccccccc}
\hline Sesudah & Regression & 50,532 & 2 & 25,266 & 146,874 & 0,000 \\
adopsi & Residual & 10,494 & 61 & 0,172 & & \\
penuh & Total & 61,026 & 63 & & & \\
IFRS & & & & & & \\
$(2012-$ & & & & & & \\
$2015)$ & & & & & & \\
\hline
\end{tabular}

Sumber: data sekunder yang diolah, 2017

\section{b. Uji Koefisien Determinasi}

Hasil pengujian pada tabel 8 menunjukkan besarnya nilai adjusted $R^{2}$ pada periode sebelum dan sesudah adopsi penuh IFRS adalah 0,857 dan 0,822 . Hal tersebut berarti pada periode sebelum adopsi penuh IFRS sebesar $85,7 \%$ variasi harga saham dapat dijelaskan oleh variasi dari kedua variabel independen EPS dan BVPS. Sedangkan sisanya $(100 \%-85,7 \%=$ $14,3 \%$ dijelaskan oleh sebab-sebab lain diluar model. Sama halnya dengan periode sesudah adopsi penuh IFRS, dimana $82,2 \%$ variasi harga saham dapat dijelaskan oleh variasi dari kedua variabel independen EPS dan BVPS. Sedangkan sisanya $(100 \%-82,2 \%=$ $17,8 \%$ ) dijelaskan oleh sebab-sebab lain diluar model.

Tabel 8

Hasil Uji Koefisien Determinasi

\begin{tabular}{ccccc}
\hline Periode & $\mathrm{R}$ & $\begin{array}{c}\mathrm{R} \\
\text { Square }\end{array}$ & $\begin{array}{c}\text { Adjusted } R \\
\text { Square }\end{array}$ & Std. Error \\
\hline $\begin{array}{c}\text { Sebelum adopsi penuh IFRS (2010- } \\
\text { 2011) }\end{array}$ & 0,931 & 0,866 & 0,857 & 0,35631 \\
\hline $\begin{array}{c}\text { Sesudah adopsi penuh IFRS (2012- } \\
\text { 2015) }\end{array}$ & 0,910 & 0,828 & 0,822 & 0,41476 \\
\hline
\end{tabular}

Sumber: data sekunder yang diolah, 2017

c. Chow Test

Hasil pengujian pada tabel 9 menunjukkan besarnya nilai Residual Sum of Square (RSS) adalah sebagai berikut:

$$
\begin{aligned}
& \mathrm{RSSr}=14,450 \\
& \mathrm{RSSur}=\mathrm{RSS} 1+\mathrm{RSS} 2=3,682+ \\
& 10,494=14,176
\end{aligned}
$$

$$
\begin{aligned}
& \mathrm{F}=\frac{(\mathrm{RSSr}-\mathrm{RSSur}) / \mathrm{k}}{(\mathrm{RSSur}) /(\mathrm{n} 1+\mathrm{n} 2-2 \mathrm{k})} \\
& \mathrm{F}=\frac{(14,450-14,176) / 3}{14,176 /(32+64-(2 \times 3))}=\frac{0,274 / 3}{14,176 / 90}=\frac{0,091333}{0,157511}=0,57985
\end{aligned}
$$

Dari tabel $\mathrm{F}$ dengan $\mathrm{df}$ pembilang $=3$ dan $\mathrm{df}$ penyebut $=90$ tingkat signifikansi 0,05 maka di dapat nilai $\mathrm{F}$ tabel sebesar 2,71. Oleh karena $F$ hitung $<\mathrm{F}$ tabel yaitu $0,57985<2,71$, maka dapat disimpulkan bahwa tidak terdapat perbedaan relevansi nilai informasi akuntansi sebelum dan sesudah adopsi penuh IFRS pada perusahaan indeks LQ 45 yang terdaftar di Bursa Efek Indonesia (BEI) periode 2010-2015. 
Tabel 9

Residual Sum of Square

\begin{tabular}{cccc}
\hline Tahun & Model & Sum of Square & Sig. \\
\hline $\begin{array}{c}\text { Sebelum adopsi penuh IFRS (2010- } \\
\text { 2011) }\end{array}$ & Residual & 3,682 & 0,000 \\
\hline $\begin{array}{c}\text { Sesudah adopsi penuh IFRS (2012- } \\
\text { 2015) }\end{array}$ & Residual & 10,494 & 0,000 \\
\hline Total (2010-2015) & Residual & 14,450 & 0,000 \\
\hline
\end{tabular}

Sumber: data sekunder yang diolah, 2017

\subsection{Pembahasan}

Hasil pengujian relevansi nilai informasi akuntansi sebelum dan sesudah adopsi penuh IFRS dapat dilihat dari dua hal, yaitu berdasarkan hasil uji Chow dan uji koefisien determinasi. Berdasarkan pada hasil uji Chow menunjukkan bahwa tidak terdapat perbedaan relevansi nilai informasi akuntansi sebelum dan sesudah adopsi penuh IFRS yaitu $\mathrm{F}$ hitung $(0,57985)$ lebih kecil dari $F$ tabel $(2,71)$. Kemudian dalam pengujian koefisien determinasi, dimana nilai adjusted $R^{2}$ pada periode sebelum adopsi penuh IFRS sebesar $85,7 \%$ dan periode sesudah adopsi penuh IFRS sebesar $82,2 \%$. Hal tersebut berarti terjadi penurunan sebesar $3,5 \%$ bagi adjusted $R^{2}$. Penurunan pada nilai adjusted $R^{2}$ menunjukkan bahwa nilai adjusted $R^{2}$ ini tidak dapat dijelaskan melalui pengukuran harga saham, earning per share, dan book value per share sesudah adopsi penuh IFRS.

Meskipun nilai adjusted $R^{2}$ mengalami penurunan, hasil statistik deskriptif menunjukkan bahwa terjadi peningkatan rata-rata harga saham dari $10.206,4634$ menjadi $11.401,3381$, peningkatan rata-rata EPS dari 544,6709 menjadi 630,6683, serta peningkatan rata-rata BVPS dari $2.216,2588$ menjadi $3.354,538$ pada periode sebelum adopsi penuh IFRS, hal tersebut dapat terjadi karena peningkatan atau penurunan relevansi nilai informasi akuntansi tidak semata-mata hanya tergambar pada kenaikan angka-angka pada harga saham, EPS, dan BVPS saja.

Berdasarkan hasil pengujian di atas, maka dapat disimpulkan bahwa tidak terdapat perbedaan relevansi nilai informasi akuntansi sebelum dan sesudah adopsi penuh IFRS. Hasil ini penelitian ini sejalan dan mendukung penelitian terdahulu yang telah dilakukan oleh Triandi dkk. (2015), Rahmawati dan Murtini (2015), serta Cahyonowati dan Ratmono (2012), yang menyatakan bahwa tidak terdapat perbedaan relevansi nilai antara sebelum dan sesudah pengadopsian penuh IFRS. Hal yang sama terjadi pada penelitian ini yaitu tidak terdapat perbedaan relevansi nilai informasi akuntansi pada periode sebelum dan sesudah adopsi penuh IFRS di Indonesia khususnya pada perusahaan indeks LQ 45. Hasil penelitian ini juga mendukung argumentasi Karampinis dan Hevas (2011) bahwa di negara-negara code law (termasuk Indonesia), dengan karakteristik lingkungan institusional seperti perlindungan investor yang lemah, kurangnya penegakan hukum, kepemilikan terkonsentrasi, dan pendanaan yang berorientasi pada perbankan maka adopsi IFRS belum tentu dapat meningkatkan relevansi nilai informasi akuntansi. Menurut peneliti, hal ini terjadi karena perusahaan-perusahaan yang terdaftar di indeks LQ 45 merupakan perusahaanperusahaan yang memiliki likuiditas tinggi yang aktif diperdagangkan dan memiliki kinerja keuangan baik serta adanya faktor lain seperti perlambatan ekonomi global yang terjadi pada tahun 2013 yang mempengaruhi perekonomian Indonesia, dimana pertumbuhan ekonomi global menurun dari $3,1 \%$ menjadi $3,0 \%$, harga komoditas terus terkoreksi ke bawah dan ketidakpastian di pasar keuangan semakin meningkat. Kondisi tersebut dipengaruhi oleh pergeseran siklus dan tatanan ekonomi global yang terjadi di sepanjang tahun 2013. Pergeseran pertama ialah beralihnya lanskap ekonomi dunia yang ditandai oleh meningkatnya pertumbuhan ekonomi negara maju dan menurunnya pertumbuhan ekonomi negara berkembang. Pergeseran 
kedua terkait dengan berlanjutnya tren penurunan harga komoditas dunia. Pergeseran yang terakhir adalah mulai beralihnya arus modal dunia, dipengaruhi berakhirnya era kebijakan moneter longgar di AS.

\section{SIMPULAN DAN SARAN}

Berdasarkan hasil analisis data dan pebahasan yang telah diuraikan pada bab sebelumnya, maka dapat ditarik kesimpulan bahwa adopsi penuh IFRS tidak berpengaruh terhadap relevansi nilai informasi akuntansi pada perusahaanperusahaan yang terdaftar dalam indeks LQ 45.

Beberapa saran yang dapat dikemukakan sehubungan dengan keterbatasan penelitian yaitu bagi investor dapat menggunakan informasi nilai laba dan nilai buku ekuitas yang dipublikasikan oleh perusahaan dalam laporan keuangannya sebagai acuan untuk menilai kinerja perusahaan serta sebagai pertimbangan untuk menilai prospek kinerja perusahaan di masa yang akan datang, sehingga dapat membentuk kepercayaan investor dalam rangka pengambilan keputusan untuk berinvestasi. Kedua, bagi penelitian selanjutnya adalah menggunakan indeks perusahaan lain yang tidak terpengaruh dengan adanya kondisi perekonomian global seperti indeks syariah, menggunakan harga rata-rata saham, dan dapat menggunakan metode pengujian lain.

\section{DAFTAR PUSTAKA}

Badan Pengawas Pasar Modal dan Lembaga Keuangan (Bapepam dan LK) (2011). Penyampaian Laporan Keuangan Berkala Emien atau Pengusaha Publik, Peraturan Nomor KEP-346/BL/2011.

Bursa Efek Indonesia, https://www.idx.co.id/, diakses 24 Februari 2017.

Cahyonowati, N., dan Ratmono D (2012). Adopsi IFRS dan Relevansi Nilai Informasi Akuntansi, Jurnal Akuntansi Dan Keuangan, Vol. 14,
No. 2, November 2012: 105-115, Universitas Diponegoro.

Cooper, Donald R., \& Schindler, Pamela S. (2014). Business Research Methods, Twelfth Edition, International Edition, New York: McGraw Hill.

Daftar Perusahaan LQ 45, https://www.sahamok.com/, diakses 24 Februari 2017

Fama, Eugene F. (1970). Efficient Capital Markets: A Review of Theory and Empirical Work, The Journal of Finance, Vol. 25, No. 2, Papers and Proceedings of the Twenty-Eighth Annual Meeting of the American Finance Association New York, N.Y. December, 28-30, 1969 (May, 1970), pp. 383-417.

Fatchan, Ilham N., dan Trisnawati Rina (2016). Pengaruh Good Corporate Governance Pada Hubungan Antara Sustainability Report dan Nilai Perusahaan (Studi Empiris Perusahaan Go Public di Indonesia Periode 2014-2015), Riset Akuntansi dan Keuangan Indonesia, 1(1).

Francis, Jennifer and Katherine Schipper (1999). Have Financial Statements Lost Their Relevance?, Journal of Accounting Research, Vol. 37, No. 2 (Autumn, 1999), pp. 319-352.

Ghozali, Imam (2016). Aplikasi Analisis Multivariete dengan Program IBM SPSS 23, Edisi 8, Semarang: Badan Penerbit Universitas Diponegoro.

Gitman, Lawrence J., \& Chad J. Zutter (2012). Principles of Managerial Finance, $13^{\text {th }}$ Edition, United States of America: Pearson Education, Inc.

Gujarati, Damodar N. (2003). Basic Econometrics, Fourth Edition, New York: The McGraw-Hill Companies, Inc 
Harga Saham, https://finance.yahoo.com/, diakses 24 Februari 2017.

IFRS, http://www.ifrs.com/, diakses 2 Juni 2017.

Ikatan Akuntan Indonesia (IAI) (2015). Standar Akuntansi Keuangan PER EFEKTIF 1 Januari 2015, Jakarta: Penerbit Ikatan Akuntan Indonesia.

Karampinis, N. \& Hevas, D. (2011). Mandating IFRS in an Unfavorable Environment: The Greek Experience, The International Journal of Accounting, 46, 304-332.

Kieso, D. E., Weygandt, J. J., \& Kimmel, P. D (2011). Financial Accounting, IFRS Edition, United States of America: John Wiley \& Sons.

Kieso, D. E., Weygandt, J. J., \& Warfield, T. D (2014). Intermediate Accounting, Second Edition, IFRS Edition, United States of America: John Wiley \& Sons.

Kieso, D. E., Weygandt, J. J., \& Kimmel, P. D (2016). Accounting Principles, Twelfth Edition, International Student Version, United States of America: John Wiley \& Sons.

Kusuma, Hadri (2006), Dampak Manajemen Laba terhadap Relevansi Informasi Akuntansi: Bukti Empiris dari Indonesia, Jurnal Akuntansi Dan Keuangan, Vol. 8, No. 1, Mei 2006: 1-12, Universitas Kristen Petra, Surabaya.

Rahmawati, Lusiana dan Henny Murtini (2015). Kualitas Informasi Akuntansi Pra dan Pasca Adopsi IFRS, Accounting Analysis Journal 4 (2), hal 1-9.

Rochmatullah, Mahameru R. dan Endah T. Susilowati (2014). IFRS dan Kualitas Informasi Investasi (Studi Empiris pada Perusahaan Go Publik di Indonesia 2010-2013), Syariah Paper
Accounting FEB UMS, Universitas Muhammadiyah Surakarta.

Scott, William R. (2015). Financial Accounting Theory, 7th edition, USA: Pearson Canada Inc.

Sukma, Made Anggia P., I Ketut Yadnyana (2016). Komparasi Relevansi Nilai Informasi Akuntansi dan Manajemen Laba Sebelum dan Sesudah Adopsi IFRS, E-Jurnal Ekonomi dan Bisnis Universitas Udayana 5.4.

Suprihatin, Siti, Elok Tresnaningsih (2013). Dampak Konvergensi International Financial Reporting Standards Terhadap Nilai Relevan Informasi Akuntansi, Jurnal Akuntansi dan Keuangan Indonesia, Desember Volume 10 Nomor 2, hal 171-183.

\begin{tabular}{ccr} 
Suwardjono (2010). & Teori & Akuntansi: \\
Pengungkapan & dan & Sarana \\
Interpretatif, & Edisi & Ketiga, \\
\multicolumn{2}{l}{ Yogyakarta: Penerbit BPFE. }
\end{tabular}

Syagata, Gupitasari Syahbi dan Daljono (2014). Analisis Komparasi Relevansi Nilai Informasi Akuntansi Sebelum dan Sesudah Konvergensi IFRS di Indonesia (Studi Empiris pada Perusahaan Manufaktur yang Terdaftar di BEI Periode 20112012), Diponegoro Journal of Accounting, Volume 3, Nomor 3, Tahun 2014, Halaman 1-11.

Triandi, Suratno, dan Nurmala Ahmar (2015). Value Relevance dan IFRS Adoption di Indonesia: Investigasi pada Perusahaan LQ-45 Bursa Efek Indonesia, Media Riset Akuntansi, Auditing \& Informasi, April Vol. 15 No. 1, hal 116-141.

Varian, Hal R. (2010). Intermediate Microeconomic, A Modern Approach, International Student Edition, $8^{\text {th }}$ Edition, United States of America: W.W. Norton \& Company, Inc. 
Varian, Hal R. (1992). Microeconomic Analysis, Third Edition, United States of America: W.W. Norton \& Company, Inc.

Wulandari, Trisninik Ratih dan Arum Kusumaningdyah Adiati (2015). Perubahan Relevansi Nilai Dalam Informasi Akuntansi Setelah Adopsi IFRS, Jurnal Akuntansi Multiparadigma JAMAL, Volume 6, Nomor 3, Halaman 341-511. 